\title{
Expressional and Functional
}

Characterization of Intracellular pH Regulators and Effects of Ethanol in Human Oral Epidermoid Carcinoma Cells

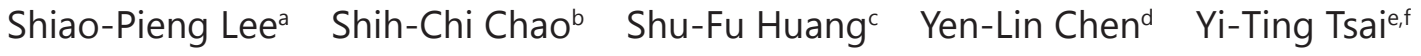 \\ Shih-Hurng Loh ${ }^{\text {b,g }}$
}

\begin{abstract}
aDivision of Oral and Maxillofacial Surgery, Department of Dentistry, School of Dentistry, Tri-Service General Hospital and National Defense Medical Center, Taipei, 'braduate Institute of Life Sciences, National Defense Medical Center, Taipei, 'Department of Pharmacy Practice, Tri-Service General Hospital, National Defense Medical Center, Taipei, dDepartment of Radical Diagnostic, Taoyuan Armed Forced General Hospital, Taoyuan, ${ }^{e}$ Graduate Institute of Medical Sciences, National Defense Medical Center, Taipei, 'Division of Cardiovascular Surgery, Department of Surgery, Tri-Service General Hospital, National Defense Medical Center, Taipei, ${ }^{\circ}$ Department of Pharmacology, National Defense Medical Center, Taipei, Taiwan
\end{abstract}

\section{Key Words}

Human Oral Epidermoid Carcinoma (OEC-M1) Cells • Ethanol • Intracellular pH Transporters • $\mathrm{BCECF} \cdot \mathrm{Na}^{+}-\mathrm{H}^{+}$Exchanger (NHE) $\bullet \mathrm{Na}^{+}-\mathrm{HCO}_{3}{ }^{-}$Cotransporter (NBC)

\begin{abstract}
Background/Aims: To functionally characterize intracellular $\mathrm{pH}\left(\mathrm{pH}_{\mathrm{i}}\right)$ regulating mechanisms, such as $\mathrm{Na}^{+}-\mathrm{H}^{+}$exchanger (NHE) and $\mathrm{Na}^{+}-\mathrm{HCO}_{3}{ }^{-}$co-transporter (NBC), and further examine effects of ethanol on the $\mathrm{pH}_{\mathrm{i}}$ regulating mechanism in human oral epidermoid carcinoma (OEC-M1) cells. Methods: OEC-M1 cells were a gift from Tri-Service General Hospital. Changes of $\mathrm{pH}_{\mathrm{i}}$ were detected by microspectrofluroimetry with a $\mathrm{pH}$-sensitive fluorescent dye, BCECF. Isoforms of transporters were examined by Western blot technique. Results: i) the steadystate $\mathrm{pH}_{i}$ value shifted from alkaline $(7.35 \sim 7.49)$ to acidic $(7.0 \sim 7.03)$ following acid/base impacts; ii) in HEPES-buffer system, $\mathrm{pH}_{\mathrm{i}}$ recovery following induced-acidification was totally blocked by either removing $[\mathrm{Na}]_{\circ}^{+}$or adding HOE 694 (a NHE1 specific inhibitor), which demonstrates existence of $\mathrm{NHE1}$; iii) in $\mathrm{HCO}_{3}-\mathrm{CO}_{2}$-buffer system, the $\mathrm{pH}_{\mathrm{i}}$ recovery following induced-acidification was entirely blocked by either removing $[\mathrm{Na}]_{0}^{+}$or adding $\mathrm{HOE} 694$ plus DIDS (a NBC specific inhibitor), which suggests existence of $\mathrm{Na}^{+}$- and $\mathrm{HCO}_{3}^{-}$-dependent acidextruder, i.e. NBC; iv) the isoforms of the two acid extruders were NHE1, NBCn1, NBCe1 and NDCBE; v) ethanol (10-1000 mM) showed a biphasic and concentration-dependent effect on resting $\mathrm{pH}_{i}$ (i.e. increase then decrease) by changing the activity of NHE1 and NBC accordingly; vi) treatment with ethanol for $24 \mathrm{hr}(\geq 300 \mathrm{mM})$ significantly inhibited the expression of

Dr. Shih-Hurng Loh

and Dr. Shiao-Pieng Lee

Department of Pharmacology and Department of Dentistry, National Defense Medical

Center, No.161, Sec. 6, Minquan E. Rd., Neihu Dist., Taipei 11490, (Taiwan, R.O.C.)

Tel. 886-2-87924861, E-Mail shloh@ndmctsgh.edu.tw shiao-pieng@yahoo.com.tw
\end{abstract}


NHE1, NBCn1 and NDCBE, while up-regulated NBCe1. Conclusions: Ethanol affects $\mathrm{pH}_{\mathrm{i}}$ in a concentration-dependent manner by changing function and expression of NHE1 and NBC isoforms in OEC-M1 cells.

(C) 2018 The Author(s)

Published by S. Karger AG, Basel

\section{Introduction}

Oral cancer is the 11th most common malignancy in the world [1]. About $90 \%$ of oral cancers are subtyped to oral epidermoid carcinoma [2]. Eight biological capabilities have been comprised as the hallmarks of cancer that include sustaining proliferative signaling, evading growth suppressors, resisting cell death, enabling replicative immortality, inducing angiogenesis, changing energy metabolism, evading immune destruction, and activating invasion and metastasis [3]. Alterations in extracellular $\mathrm{pH}\left(\mathrm{pH}_{\mathrm{e}}\right)$ and intracellular $\mathrm{pH}\left(\mathrm{pH}_{\mathrm{i}}\right)$ trigger many pathological processes, including cancer [4]. The microenvironment within tumors is hypoxic, which overproduces acids mainly by glycolytic metabolism, resulting in very acidic $\mathrm{pH}_{\mathrm{e}}$ condition [5]. Such low $\mathrm{pH}_{\mathrm{e}}$ inside solid tumors is mainly attributable to the $\mathrm{pH}_{\mathrm{i}}$ extruders, such as $\mathrm{Na}^{+}-\mathrm{H}^{+}$exchanger (NHE) and $\mathrm{Na}^{+}-\mathrm{HCO}_{3}^{-}$exchanger (NBC) $[6,7]$. Indeed, NHE activation has been found to enhance tumor cell migration and invasion by creating a distinct cell surface $\mathrm{pH}$ gradient and invadopodial-dependent extracellular matrix degradation in human endometrial cancer cells, human breast carcinoma and melanoma cells [8-12]. On the other hand, change of $\mathrm{pH}_{\mathrm{i}}$ affects many mammalian cellular functions, such as ion channel permeability [13], cell volume [14], proliferation, apoptosis, differentiation and metastasis $[15,16]$. The rise in $\mathrm{pH}_{\mathrm{i}}$ through activation of the NHE that modulated by growth factors plays an important role in growth control in tumor tissues $[17,18]$. Some of the Bcl-2 family proteins [19] and endonucleases [20] have been identified to be sensitive to apoptosis related early intracellular alkalinization [21]. Moreover, treatment with p90rsk inhibitor has been found to reduce the ethanol-induced increase in viability of cell and expression of NHE1 and Bcl-2 in hepatocellular carcinoma [22].

The $\mathrm{pH}_{\mathrm{i}}$ is precisely regulated through the combined process of active transmembrane transporters and passive intracellular buffering power $[15,23,24]$. The active membrane transporters can be separated into two main groups: acid extruders and acid loaders. Acid extrusion regulators, such as NHE and NBC, can be triggered when cells are in acidic condition $[15,25,26]$. NHE is an electroneutral housekeeping transporter that mediates the exchange of $\left[\mathrm{Na}^{+}\right]_{\mathrm{o}}$ for $\left[\mathrm{H}^{+}\right]_{\mathrm{i}}[15,25,26]$. Under HEPES-buffered media $\left(\mathrm{HCO}_{3}^{-}-\right.$free $)$, the $\mathrm{pH}_{\mathrm{i}}$ recovery from acidification through NHE can be inhibited by removal of $\left[\mathrm{Na}^{+}\right]_{0}$ or by the addition of a specific and potent NHE1 inhibitor, such as Hoe 694 [26, 27]. However, in $\mathrm{CO}_{2} / \mathrm{HCO}_{3}{ }^{-}$buffered Tyrode solution, NBC coexists with NHE to achieve acid-equivalent extrusion in many mammalian cells $[24,25,27,28]$. This cotransporter of NBC is largely (56\% to 91\%) 4, 4-diisothiocyanatostilbene-2, 2-disulphonic acid (DIDS) sensitive, while HOE 694-resistant [23, 25, 27-29]. NBC is also inhibited by removal of external $\mathrm{Na}^{+}[29$, 30]. The isoforms of $\mathrm{Na}^{+}$-dependent bicarbonate transporters include at least five members of the slc4 family: 2 electrogenic $\mathrm{Na}^{+}, \mathrm{HCO}_{3}{ }^{-}$cotransporters (NBCe1/SLC4A4 and NBCe2/ SLC4A5), 1 electroneutral $\mathrm{Na}^{+}, \mathrm{HCO}_{3}^{-}$cotransporter (NBCn1/SLC4A7) and $2 \mathrm{Na}^{+}$-dependent $\mathrm{Cl}^{-} / \mathrm{HCO}_{3}^{-}$exchangers (NCBE/SLC4A10 and NDCBE/SLC4A8) [15, 31]. In vascular smooth muscle cells of rat and mice mesenteric small arteries, one and only isoform of NBC has been identified, i.e. NBCn1 (SLC4A7; electroneutral) [15]. However, in our previous study, mRNA/protein levels of three different isoforms of NBC were detected, i.e. NBCn1, NBCe1 (SLC4A4; electrogenic) and NBCe2 (SLC4A5) in human renal artery smooth muscle cells [25]. However, no related knowledge of OEC-M1 cells has been reported.

Although the relationship between alcohol consumption and cardiovascular system function is ambiguous, the alcohol consumption has been long linked to cancer risk [32, 33]. Previous studies indicate that alcohol induced DNA damage and oxidative stress are associated with cancer risk, and promoted tumor metastasis [34-36]. According to epidemiological evidence, alcohol might play a causative role in developing oral cancer [37-

\section{KARGER}


Lee et al.: Effects of Ethanol on pH Regulators in Oral Cancer Cells

39]. The risk of oral cancer demonstrates strong dose-dependent of alcohol: from 1.75 to 6.01 with increased amounts of alcohol drinking from $25 \mathrm{~g}$ /day to $100 \mathrm{~g} /$ day, respectively $[37,39,40]$. Our previous research shows that ethanol (30-1000 $\mathrm{mM})$ induced a biphasic and concentration-dependent change in resting $\mathrm{pH}_{\mathrm{i}}$ in human myocardial tissue and umbilical cord blood stem cells by altering the activity of the two acid extruders, i.e. NHE and NBC $[23,41]$. Moreover, it has been shown that ethanol treatment $(10 \sim 30 \mathrm{mM})$ induced cell proliferation mainly by increasing the activities of ERK1 and p90rsk in HepG2 cells, and the maximum effects were shown at the concentration of $20 \mathrm{mM}$ both [22]. However, the related knowledge of ethanol on $\mathrm{pH}_{\mathrm{i}}$ regulators is none in OEC-M1 cells. In the light of the importance of $\mathrm{pH}_{\mathrm{i}}$ regulation and the serious problem of alcohol abuse in the modern society, the aim of this study is to investigate the effect of ethanol on functional $\mathrm{pH}_{\mathrm{i}}$ acid extruding mechanism in OEC-M1 cells.

\section{Materials and Methods}

\section{Cell culture}

Primary human oral epidermoid carcinoma (OEC-M1) cells (gift from Tri-Service General Hospital, Taipei, Taiwan) were cultured at $37^{\circ} \mathrm{C}$ with RPMI 1640 media contained serum (10\%; Biological Industries, USA) and penicillin/streptomycin (1\%). The culture media was renewed every 2-3 days, and routinely subcultured and further experiments were conducted when the cells reached $70-80 \%$ in growth density.

\section{Western blotting}

The procedure has been described in detail in our previous reports [25]. For immunoblotting analysis, the individual membranes were exposed to anti-SLC9A1 (NHE1, TA328914, 1:1000, OriGene Technologies), anti-SLC4A4 (NBCe1, TA332616, 1:1000, OriGene Technologies), anti-SLC4A7 (NBCn1, AP5655b, 1:1000, Abgent), anti-SLC4A8/10 (NDCBE, OAEC03098, 1:1000, Aviva Systems Biology), and anti- $\beta$-actin (GTX100118, 1:5000, GeneTex) at $4^{\circ} \mathrm{C}$ overnight.

\section{Weak acid/base pre-pulse technique}

$\mathrm{NH}_{4} \mathrm{Cl}$ pre-pulse techniques were used to induce acute intracellular acid loading, and the procedure has been described in detail in our previous reports $[25,26,42]$. This method can be explained by 4 phases as shown in the most left part of Fig. 1C: phase 1 (rapid alkalization), phase 2 (slow recovery), phase 3 (rapid acidification) and phase $4\left(\mathrm{pH}_{\mathrm{i}}\right.$ regulation). Thus, the acid extruder activity was measured as the slope of recovery from $\mathrm{NH}_{4} \mathrm{Cl}(20 \mathrm{mM})$ induced intracellular acidification.

\section{In situ calibration of intracellular $p H$ fluorescent dye BCECF in OEC-M1 cells}

To measure $\mathrm{pH}_{\mathrm{i}}$ and characterize $\mathrm{pH}_{\mathrm{i}}$ regulating mechanism, OEC-M1 cells were detected by microspectrofluroimetry with a pH-sensitive fluorescent dye, BCECF (2',7'-bis(2-carboxethyl)-5(6)-carboxyfluorescein-acetoxymethyl; $6.25 \mu \mathrm{g} / \mathrm{ml}$, Molecular Probes), and the procedure has been described in detail in our previous reports $[25,28]$. The result of in situ calibration curve by using microspectrofluroimetry technique with nigericin $(10 \mu \mathrm{M})$ has been shown in the very first part of Result section, and Fig. 1A, B. Note that nigericin acted as a potassium ionophore to equalize the $\mathrm{pH}_{\mathrm{i}}$ to the $\mathrm{pH}_{\mathrm{e}}$.

To measure the chronic change of resting $\mathrm{pH}_{\mathrm{i}}$, cells in 24 -well plates were loaded with $6.25 \mu \mathrm{g} / \mathrm{ml}$ BCECF-AM in cultured medium at $37^{\circ} \mathrm{C}$ for $30 \mathrm{~min}$, and the procedure has been described in detail by other groups $[43,44]$. To keep the $\mathrm{CO}_{2}$ partial pressure stable during the $\mathrm{pH}$ measurements in the reader, the well was covered with a plastic lid. The change of solution was done outside the reader by a pipette. In brief, we aspirated the loading medium and washed with standard HEPES-buffered solution for 2 times. Subsequently, the HEPES- or $5 \% \mathrm{CO}_{2} / \mathrm{HCO}_{3}$-buffered solution contained with different concentrations of ethanol were added to the cell and cultured at $37^{\circ} \mathrm{C}$ for the designed hour. After the treatment, 24 -well plates were moved to the Synergy 2Multi-Mode Reader (BioTek, USA) and the ratios of excitation $490 \pm 10$ $\mathrm{nm}$ and $440 \pm 10 \mathrm{~nm}$ to emission $530 \pm 10 \mathrm{~nm}$ were recorded every $10 \mathrm{~s}$ for $10 \mathrm{~min}$. For the in situ calibration of 24-well plate, after BCECF-AM loading, 5 wells of the 24-well plate were washed twice with calibration solution of 5 different $\mathrm{pH}$ values (i.e. 5.5, 6.5, 7.0, 7.5 and 8.5) without nigericin, and then calibration solution 


\section{Cellular Physiology Cell Physiol Biochem 2018;47:2056-2068 \\ \begin{tabular}{l|l} 
DOI: 10.1159/000491473 & Ond Biochemistry 2018 The Author(s). Published by S. Karger AG, Basel \\
www.karger.com/cpb
\end{tabular} \\ Lee et al.: Effects of Ethanol on pH Regulators in Oral Cancer Cells}

with nigericin $(10 \mu \mathrm{M})$ was added at $37^{\circ} \mathrm{C}$ for $10 \mathrm{~min}$, respectively. Subsequently, the plate was ready for the fluorescence detection both for the in situ calibration on the 5 nigericin-contained wells (data of calibration was now shown) and the designed $\mathrm{pH}_{\mathrm{i}}$ experiments on the rest 19 wells.

\section{Chemicals and solutions}

Standard HEPES-buffered Tyrode solution (air equilibrated) was composed of (in mM): $140 \mathrm{NaCl}, 4.5$ $\mathrm{KCl}, 1 \mathrm{MgCl}_{2}, 2.5 \mathrm{CaCl}_{2}, 11$ glucose, 20 HEPES. In $\mathrm{Na}^{+}$free HEPES solution, $140 \mathrm{NaCl}$ were replaced with 140 NMDG. Standard bicarbonate-buffered Tyrode solution (equilibrated with $5 \% \mathrm{CO}_{2} / 23 \mathrm{mM} \mathrm{HCO}_{3}^{-}$) was the same as standard HEPES-buffered Tyrode solution, except that the concentration of $\mathrm{NaCl}$ was reduced to 117 $\mathrm{mM}$ and $20 \mathrm{mM}$ HEPES were replaced with $23 \mathrm{mM} \mathrm{NaHCO}_{3}$. In $\mathrm{NH}_{4} \mathrm{Cl}$ pre-pulse solution, $\mathrm{NH}_{4} \mathrm{Cl}$ was added directly to solution without osmotic compensation. All different solutions were adjusted to 7.4 with $4 \mathrm{~N}$ $\mathrm{NaOH}, 4 \mathrm{~N} \mathrm{HCl}$ and $\mathrm{KOH}$, respectively, at $37^{\circ} \mathrm{C} .4$, 49-diisothiocyanatostilbene-2, 29-disulphonic acid (DIDS) and HOE 694 (3-methylsulfonyl-4-piperidinobenzoyl, guanidine hydrochloride) were added to solutions shortly before use.

HOE 694 was kindly provided by Sanofi-Aventis (Germany). All other chemicals were purchased from Sigma (UK) and Merck (UK).

\section{Statistical analysis}

Statistical analysis was performed using Student's t-test and one-way ANOVA. The level of significance was set at ${ }^{*} p<0.05$ or ${ }^{* *} p<0.01$ verse to control. All data are expressed as means \pm standard error of the mean (SEM).

\section{Results}

\section{In situ calibration standard curve and equation}

Fig. 1A showed the emission ratio observed on perfusion with six different $\mathrm{pH}$ calibration solutions (5.5 9.5) in OEC-M1 cells. The maximum and minimal emitted ratio (Rmax and Rmin) of $530 \mathrm{~nm}$ at $490 \mathrm{~nm}$ and $440 \mathrm{~nm}$ excitations were obtained from perfusion with pH 9.5 and 5.5 calibration solution, respectively. As shown in Fig. 1B, the mean apparent dissociation constant $\left(\mathrm{pK}_{\mathrm{a}}\right.$ ) at $37^{\circ} \mathrm{C}$ could be derived from the standard nonlinear curve. The below equation $[25,26,45]$ was used to convert the fluorescent ratio into $\mathrm{pH}_{\mathrm{i}}$ :

$$
\mathrm{pH}_{\mathrm{i}}=\mathrm{pK}_{\mathrm{a}}+\log \left[\left(\mathrm{R}_{\max }-\mathrm{R}\right) /\left(\mathrm{R}-\mathrm{R}_{\min }\right)\right]+\log \left(\mathrm{F}_{440 \min } / \mathrm{F}_{440 \max }\right)
$$

The $\mathrm{R}$ is the ratio of the $530 \mathrm{~nm}$ fluorescence emission at $490 \mathrm{~nm}$ and $440 \mathrm{~nm}$ excitation, and $\mathrm{F}$ is the fluorescence at $490 \mathrm{~nm}$ and $440 \mathrm{~nm}$ excitation. The maximum and minimal values were obtained from the data curve and the $\mathrm{pK}_{\mathrm{a}}$ (-log of dissociation constant) is 7.22. Therefore, our present study has provided the equation of standard calibration curve in situ for OEC-M1 cells as shown in Fig. 1B.

\section{Resting and new steady-state intracellular $\mathrm{pH}$ value}

Under the HEPES-buffered solution, the original resting $\mathrm{pH}_{\mathrm{i}}$ value was alkaline (7.49 $\pm 0.05 ; \mathrm{n}=40)$, while shifted to the new acidic steady-state value of $\mathrm{pH}_{\mathrm{i}}(7.00 \pm 0.09 ; \mathrm{n}=40$; $\mathrm{p}<0.05$ ) after intracellular acid/base impact by applying $\mathrm{NH}_{4} \mathrm{Cl}$ pre-pulse for 3 times or more, as shown in the Fig. 1C. Similar results were found under $\mathrm{CO}_{2} / \mathrm{HCO}_{3}^{-}$-buffered solution, the $\mathrm{pH}_{\mathrm{i}}$ value was alkaline at the beginning $(7.35 \pm 0.06 ; \mathrm{n}=25)$ and shifted to steady-state but more acidic afterwards ( $7.03 \pm 0.07 ; n=25 ; p<0.05)$, as shown in the Fig. 1 D.

\section{Functional identification of intracellular acid extruders}

As shown in the Fig. $2 \mathrm{~A}$ and $2 \mathrm{~B}$, the $\mathrm{pH}_{\mathrm{i}}$ recovery after $\mathrm{NH}_{4} \mathrm{Cl}$-induced intracellular acidification was entirely blocked by perfusion with $\mathrm{Na}^{+}$free solution and application of $300 \mu \mathrm{M}$ HOE 694 (a specific inhibitor of NHE-1) in HEPES-buffered system, respectively. Histograms of Fig. $2 \mathrm{C}$ show the $\mathrm{pH}_{\mathrm{i}}$ recovery slope $(\%)$ following induced intracellular acidification averaged for 6 experiments similar to those shown in A and B, respectively. It demonstrated 
Fig. 1. In situ calibration of BCECF fluorescent dye, resting $\mathrm{pH}_{\mathrm{i}}$ and kinetic steady-state $\mathrm{pH}_{\mathrm{i}}$ in OEC-M1 cells. (A) The trace shows the BCECF fluorescence (510 nm emission at $490 \mathrm{~nm}$ and 440 $\mathrm{nm}$ excitations) that calibrated by superfusing with 6 different $\mathrm{pH}$ (5.5-9.5) of nigericin solutions in OEC-M1 cells. (B) The curve and equation show the relationship of BCECF fluorescence ratio and $\mathrm{pH}_{\mathrm{i}}$ that averaged from 6 similar experiments as shown in A. (C, D) The above bars show the buffer system used, and the periods of application of $\mathrm{NH}_{4} \mathrm{Cl}-$ pre-pulse are shown with bars above the trace. Note that the new steady-state $\mathrm{pH}_{\mathrm{i}}$ is reached following $\mathrm{NH}_{4} \mathrm{Cl}$ pre-pulse

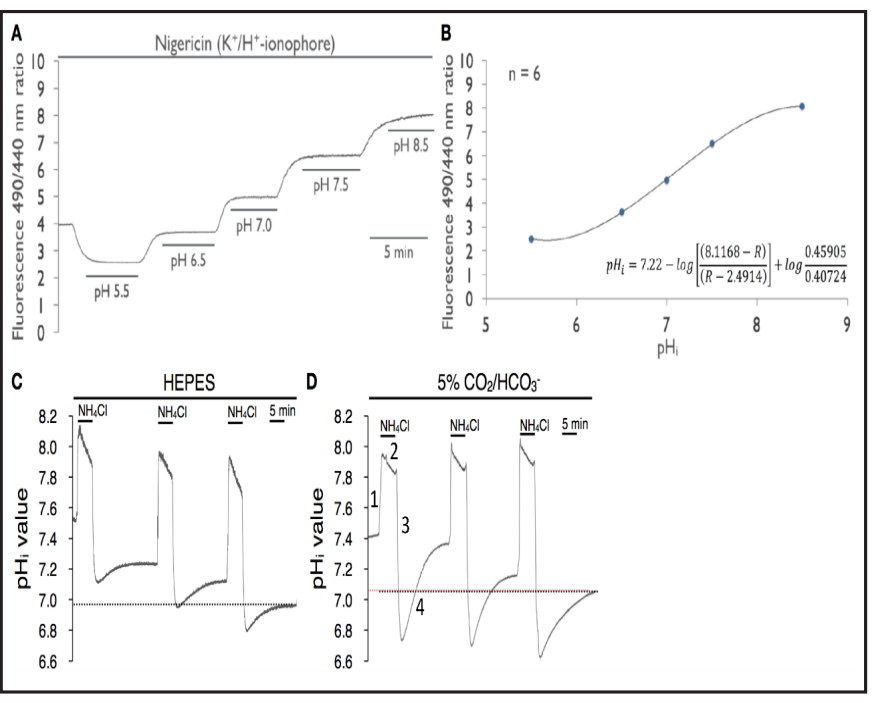
induced intracellular acidification.

that the mechanism of acidextrusion in HEPES-buffered system is purely dependent on $\mathrm{Na}^{+}-\mathrm{H}^{+}$exchanger-1 (NHE1) in OEC-M1 cells.

Under $5 \% \quad \mathrm{CO}_{2} / \mathrm{HCO}_{3}^{-}-$ buffered solution, as shown in Fig. 3, removal of $\mathrm{Na}^{+}$and application of HOE $694(300 \mu \mathrm{M})$ pulse DIDS $(400 \mu \mathrm{M})$ completely blocked $\mathrm{pH}_{\mathrm{i}}$ recovery, as shown in the Fig $3 \mathrm{~A}$ and the most right part of Fig. 3D, respectively. On the contrary, adding HOE 694 or DIDS alone only decreased $\mathrm{pH}_{\mathrm{i}}$ recovery partially (29\% and $25 \%$, respectively), as shown in Figs 3B, 3C and 3D. Histogram in

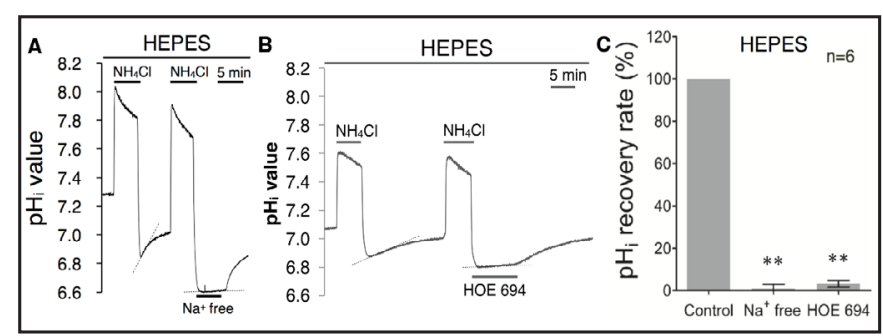

Fig. 2. Effect of $\mathrm{Na}^{+}$-free solution and $\mathrm{HOE} 694$ on $\mathrm{pH}_{\mathrm{i}}$ recovery subsequent induced intracellular acidification in HEPES-buffered condition. (A, B) The above bars show the buffer system used, and the bars above or below the trace show the application of $\mathrm{NH}_{4} \mathrm{Cl}$ and treatment. (C) Histograms show the $\mathrm{pH}_{\mathrm{i}}$ recovery slope (\%) following induced intracellular acidification averaged for 6 experiments similar to those shown in A and B, respectively. The $\mathrm{pH}_{\mathrm{i}}$ recovery rate was measured at $\mathrm{pH}_{\mathrm{i}}=6.80 \pm 0.04,{ }^{* *} \mathrm{p}<0.01$ verse to control.

Fig. 3E shows the normalization of $\mathrm{pH}_{\mathrm{i}}$ recovery rate of acid extrusion averaged for 6 experiments similar to those shown in Fig. 3A, B, C and D. Our present results indicated that the NHE and NBC functional co-exist in OEC-M1 cells.

The acute and chronic effect of ethanol on resting $\mathrm{pH}_{i}$

To explore the acute and chronic effect of ethanol on resting $\mathrm{pH}_{\mathrm{i}}$ in OEC-M1 cells, different concentrations of ethanol (10 to $1000 \mathrm{mM}$ ) were superfused under HEPES- (Fig. $4 \mathrm{~A}$ and $4 \mathrm{~B}$ ) and $5 \% \mathrm{CO}_{2} / \mathrm{HCO}_{3}^{-}$-buffered condition (Fig. $4 \mathrm{C}$ and $4 \mathrm{D}$ ). Note that the resting $\mathrm{pH}_{\mathrm{i}}$ was observed after 3 times' $\mathrm{NH}_{4} \mathrm{Cl}$ pre-pulse (Fig. not shown). The present results showed that $10-30 \mathrm{mM}$ ethanol didn't affect resting $\mathrm{pH}_{\mathrm{i}}$, while the higher concentrations of ethanol $(>100 \mathrm{mM})$ changed resting $\mathrm{pH}_{\mathrm{i}}$ significantly both in HEPES- and $\mathrm{CO}_{2} / \mathrm{HCO}_{3}^{-}-$ buffered condition, as shown in Figs. 4A and 4C, respectively. To rule out the possibility of run-down of $\mathrm{pH}_{\mathrm{i}}$ by time, the wash-out after perfusion of different concentrations of ethanol had been examined, as shown in Fig. 4B and 4D. Our present results showed that ethanol (10-1000 $\mathrm{mM})$ showed a concentration-dependent inhibitory effect on resting $\mathrm{pH}_{\mathrm{i}}(-0.01 \sim$ $0.05 \mathrm{pH}_{\mathrm{i}}$ unit) in HEPES-buffered solution, while a concentration-dependent and biphasic 
Fig. 3. Effect of $\mathrm{Na}^{+}$-free solution, $\mathrm{HOE}$ 694, DIDS and HOE 694 plus DIDS on $\mathrm{pH}_{\mathrm{i}}$ recovery subsequent induced intracellular acidification in $5 \% \mathrm{CO}_{2} / \mathrm{HCO}_{3}^{-}$-buffered condition. (A, B, C, D) The above bars show the buffer system used, and the bars above or below the trace show the application of $\mathrm{NH}_{4} \mathrm{Cl}$ and treatment. The first part of trace A, B, C, D shows a typical $\mathrm{pH}_{\mathrm{i}}$ recovery form an induced intracellular acidification in $5 \% \mathrm{CO}_{2} / \mathrm{HCO}_{3}$-buffered solution as control. The other part shows the $\mathrm{pH}_{\mathrm{i}}$ recovery slope after application of $\mathrm{Na}^{+}$free, HOE 694, DIDS, and HOE 694

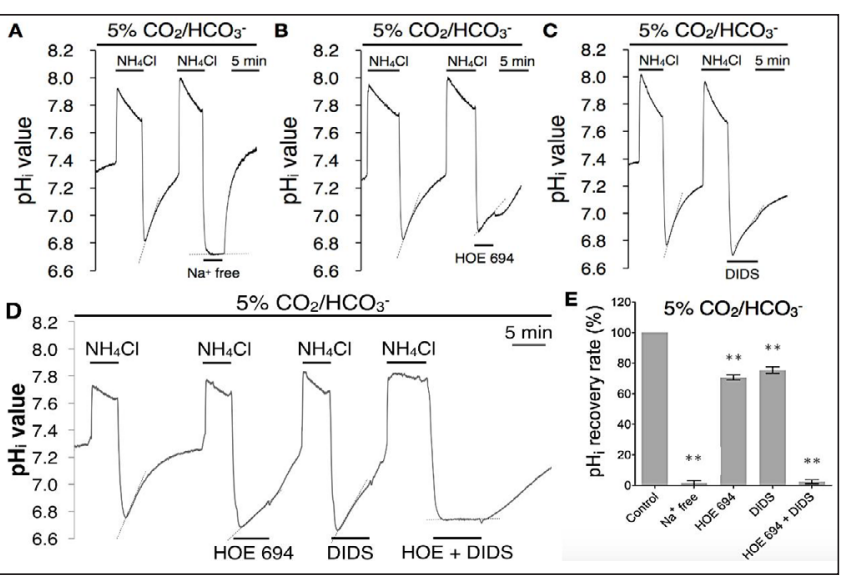
plus DIDS, respectively. (E) Histogram shows the normalization of $\mathrm{pH}_{\mathrm{i}}$ recovery rate of acid extrusion that are averaged for 6 experiments similar to those shown in $\mathrm{A}, \mathrm{B}, \mathrm{C}, \mathrm{D}$. The $\mathrm{pH}_{\mathrm{i}}$ recovery rate was measured at $\mathrm{pH}_{\mathrm{i}}=6.80 \pm 0.04, * * \mathrm{p}<0.01$ verse to control.

Fig. 4. Effect of acute and chronic treatment with ethanol (10 to $1000 \mathrm{mM}$ ) on resting $\mathrm{pH}_{\mathrm{i}}$ value in HEPES- and $\mathrm{CO}_{2} /$ $\mathrm{HCO}_{3}$-buffered solution. (A, B, C, D) The above bars show the buffer system used, and the bars above or below the trace show the acute application of ethanol. The first of $3 \mathrm{~min}$ of trace shows the resting $\mathrm{pH}_{\mathrm{i}}$ value as a control. (E) Histograms show the normalization of change of ethanol on resting $\mathrm{pH}_{4}$ averaged in 7 experiments similar to that shown in $\mathrm{A}$ and $C$, respectively. (F) Histograms show the normalization of change on resting $\mathrm{pH}_{\mathrm{i}}$ after chronic application of ethanol (24 hr) either in HEPES- or 5\% $\mathrm{CO}_{2} /$ $\mathrm{HCO}_{3}$-buffered condition, respectively. ${ }^{* *} \mathrm{p}<0.01$ verse to control of HEPESbuffered system group, $\$ p<0.01$ verse to control of $5 \% \mathrm{CO}_{2} / \mathrm{HCO}_{3}{ }^{-}$-buffered system group, ${ }^{\# \#} \mathrm{p}<0.01$ HEPES-buffered system group vs $5 \% \mathrm{CO}_{2} / \mathrm{HCO}_{3}{ }^{-}$-buffered system

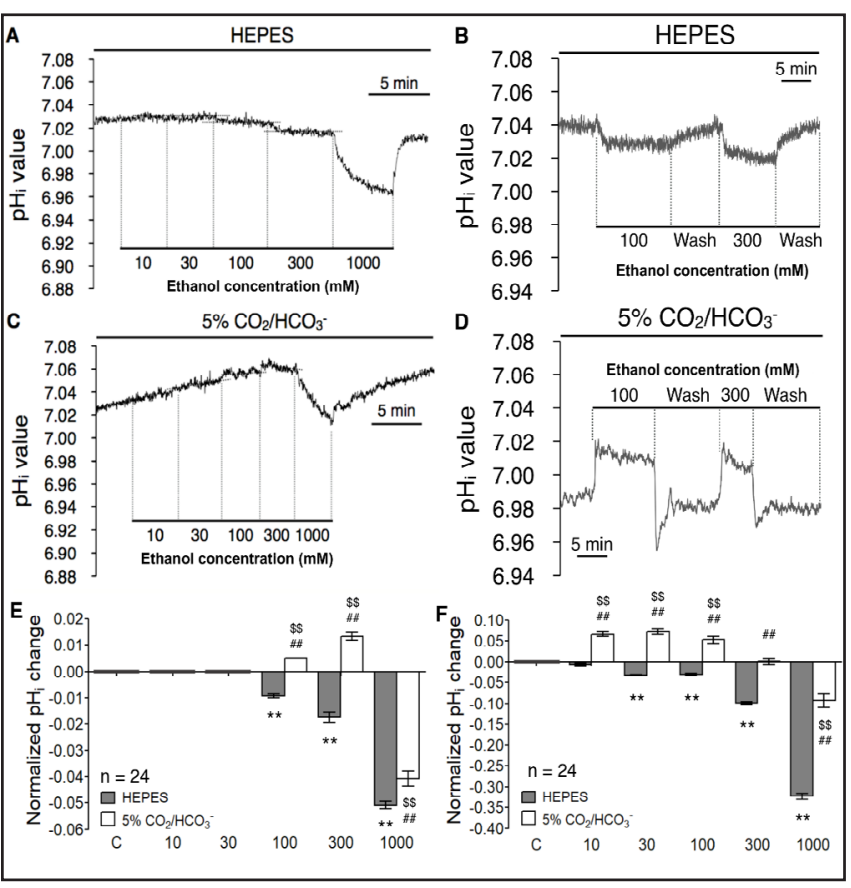
group.

effect on resting $\mathrm{pH}_{\mathrm{i}}\left(+0.01 \sim-0.05 \mathrm{pH}_{\mathrm{i}}\right.$ unit) in $\mathrm{CO}_{2} / \mathrm{HCO}_{3}$-buffered condition, as shown in histograms of Fig. 4E. Moreover, in experiments of chronic effect of ethanol on $\mathrm{pH}_{\mathrm{i}}$ (i.e. $24 \mathrm{hr}$ ), the changes are about up to five or even six times higher than that of acute treatment with ethanol, as shown in the histogram of Fig. $4 \mathrm{~F}$ (HEPES-buffered: -0.03 -0.3 pH unit; $\mathrm{CO}_{2}$ / $\mathrm{HCO}_{3}{ }^{-}$-buffered: + 0.07 -0.09 $\mathrm{pH}_{\mathrm{i}}$ unit).

\section{The effect of ethanol on the activity of NHE and NBC}

To measure the effect of ethanol on the activity of NHE, the cells were superfused with various concentrations of ethanol (10-1000 mM) during the $\mathrm{pH}_{\mathrm{i}}$ recovery following $\mathrm{NH}_{4} \mathrm{Cl}$-induced intracellular acidification in HEPES-buffered solution (Fig. 5). As shown in the Fig. $5 \mathrm{~A}$, lower concentrations of ethanol (10-30 mM) did not change $\mathrm{pH}_{\mathrm{i}}$ recovery 
in HEPES-buffered solution. In HEPES-buffered solution, adding higher concentrations of ethanol $(100-1000 \mathrm{mM})$ inhibited the $\mathrm{pH}_{\mathrm{i}}$ recovery in a concentrationdependent and reversible way, as shown in Fig. 5B-E. Note that the inhibition of NHE1 activity by $1000 \mathrm{mM}$ of ethanol was dramatically but reversibly.

To elucidate the effect of ethanol on NBC activity, the cells were superfused with of different concentrations of ethanol (10-1000 mM) during the $\mathrm{pH}_{\mathrm{i}}$ recovery following $\mathrm{NH}_{4} \mathrm{Cl}$-induced intracellular acidification in $\mathrm{CO}_{2} /$ $\mathrm{HCO}_{3}{ }^{-}$-buffered solution. As shown in the Fig. 6, lower concentrations of ethanol (10-30 mM) didn't change $\mathrm{pH}_{\mathrm{i}}$ recovery (Fig. 6A), while higher concentrations of ethanol (100-300 mM) increased $\mathrm{pH}_{\mathrm{i}}$ recovery. Note that adding the highest concentration of ethanol $(1000 \mathrm{mM})$ dramatically inhibited $\mathrm{pH}_{\mathrm{i}}$ recovery $(\sim 50 \%)$ under $\mathrm{CO}_{2} /$ $\mathrm{HCO}_{3}$-buffered condition (Fig. 6D). Histogram in Fig. 6E shows the normalization of $\mathrm{pH}_{\mathrm{i}}$ recovery

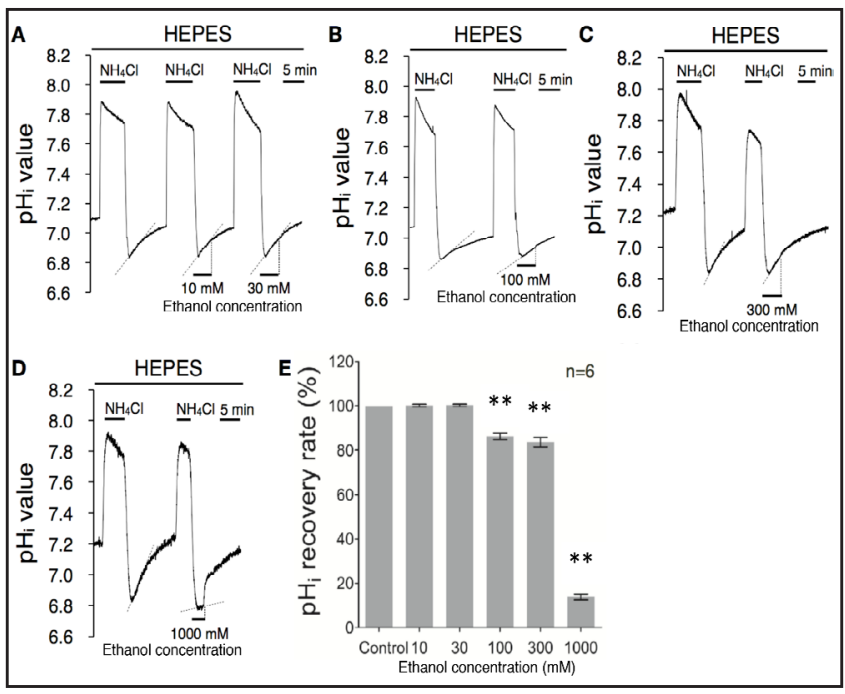

Fig. 5. Effect of acute treatment of ethanol (10 to $1000 \mathrm{mM}$ ) on $\mathrm{pH}_{\mathrm{i}}$ recovery after induced intracellular acidification in OEC-M1 cells superfused with HEPES-buffered solution. (A, B, C, D) The above bars show the buffer system used, and the bars above or below the trace show the acute application of ethanol and $\mathrm{NH}_{4} \mathrm{Cl}$. The first part of trace $\mathrm{A}, \mathrm{B}, \mathrm{C}, \mathrm{D}$ shows a typical $\mathrm{pH}_{\mathrm{i}}$ recovery form an induced intracellular acidification in HEPES-buffered solution as control. The other part shows the $\mathrm{pH}_{\mathrm{i}}$ recovery slope after application of ethanol in different concentration. (E). Histogram shows the normalization of $\mathrm{pH}_{\mathrm{i}}$ recovery rate of acid extrusion averaged in 6 experiments similar to that shown in $\mathrm{A}$, $\mathrm{B}, \mathrm{C}$ and $\mathrm{D}$, respectively. The $\mathrm{pH}_{\mathrm{i}}$ recovery rate was measured at $\mathrm{pH}_{\mathrm{i}}=6.90 \pm 0.04,{ }^{* *} \mathrm{p}<0.01$ verse to control. rate of acid extrusion averaged in 6 experiments similar to that shown in Fig. 6A, 6B, 6C and 6D, respectively. Our present results provided direct evidence that higher concentrations of ethanol showed opposite effects on activity of NHE1 and NBC, i.e. decreasing and increasing, respectively, in OEC-M1 cells.

\section{The effect of ethanol on protein expression of NHE and NBC}

In order to check the impact of ethanol on the protein expression of NHE and NBC, the characterization of isoform of NHE and NBC was first examined. Our experiments showed that the isoforms of NHE and NBC are including NHE1 (SLC9A1), NBCe1 (SLC4A4), NBCn1 (SLC4A7) and NDCBE (SLC4A8), as shown in the left part of Fig. 7A. As shown in right parts of Fig. 7A, chronic exposure of ethanol with various concentrations for 24 hours caused a significantly decreasing effect on the protein expression of NHE1, NBCn1 and NDCBE, while a dramatically increasing effect on that of NBCe1 at concentration $\geq 300 \mathrm{mM}$. These results suggested that the decreasing of resting $\mathrm{pH}_{\mathrm{i}}$ by ethanol in HEPES-buffered was due to the down-regulation of protein expression of NHE-1 and/or inhibition of functional activity. Moreover, note that $1000 \mathrm{mM}$ of ethanol caused a diverse effect on the protein expression of NBCe1 (i.e. increasing to 2.82 fold) and that of NBCn1 and NDCBE (decreasing to 0.43 fold and 0.46 fold, respectively).

\section{Discussion}

The resting $\mathrm{pH}_{i}$ and new steady-state $\mathrm{pH}_{i}$ in OEC-M1 cells

Many cellular functions are sensitive to changes of $\mathrm{pH}_{\mathrm{i}}$. Recently, dysregulated $\mathrm{pH}$ is evolving as a hallmark of cancer tissues, i.e. high $\mathrm{pH}_{\mathrm{i}}$ and low $\mathrm{pH}_{\mathrm{o}}$ that enables cancer 
Fig. 6. Effect of acute treatment of ethanol (10 to $1000 \mathrm{mM}$ ) on $\mathrm{pH}_{\mathrm{i}}$ recovery after induced intracellular acidification in OEC-M1 cells superfused with $\mathrm{CO}_{2} / \mathrm{HCO}_{3}{ }^{-}$-buffered solution. (A, B, C, D) The above bars show the buffer system used, and the bars above or below the trace show the acute application of ethanol and $\mathrm{NH}_{4} \mathrm{Cl}$. The first part of trace A, B, C, D shows a typical $\mathrm{pH}_{\mathrm{i}}$ recovery form an induced intracellular acidification in $\mathrm{CO}_{2} / \mathrm{HCO}_{3}^{-}-$ buffered solution as control. The other part shows the $\mathrm{pH}_{\mathrm{i}}$ recovery slope after application of alcohol in different concentration. (E). Histogram shows the normalization of $\mathrm{pH}_{\mathrm{i}}$ recovery

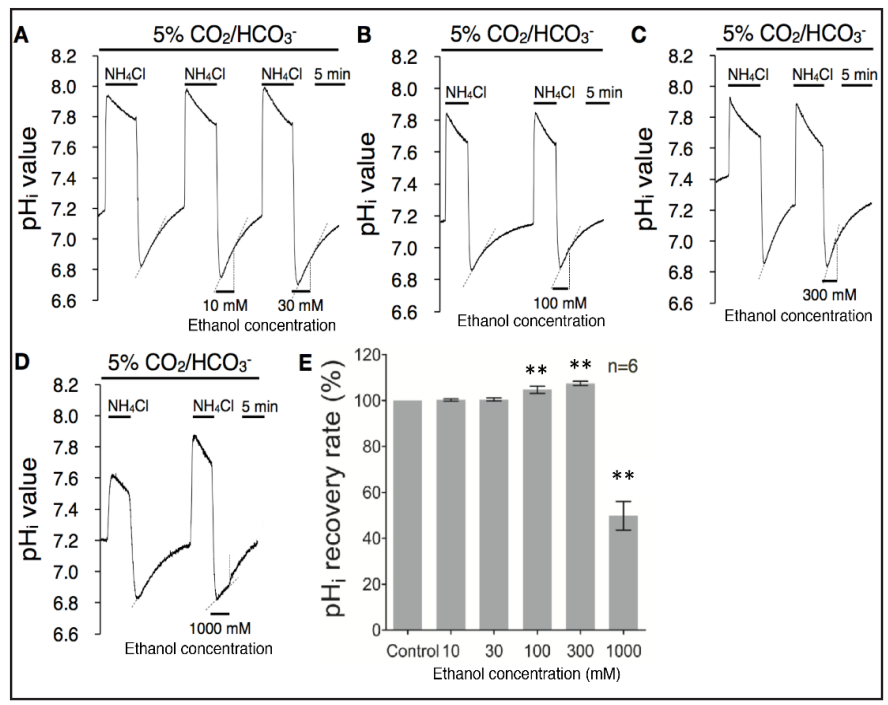
rate of acid extrusion averaged in 6 experiments similar to that shown in $\mathrm{A}, \mathrm{B}, \mathrm{C}, \mathrm{D}$, respectively. The $\mathrm{pH}_{\mathrm{i}}$ recovery rate was measured at $\mathrm{pH}_{\mathrm{i}}=$ $6.90 \pm 0.04,{ }^{* *} \mathrm{p}<0.01$ verse to control.

Fig. 7. Effect of chronic treatment of ethanol (24 hr) on isoforms of acid extruders in OEC-M1 cells. (A) The western blot results show the changes of isoforms of NHE1, NBCe1, NBCn1, NDCBE and GAPDH expression (marked at the most left) after $24 \mathrm{hr}$ treatment with ethanol (10 to 1000 $\mathrm{mM}$; marked at the top) in OEC-M1 cells. (B, C, D, E) The histogram show the relative expression ratio of NHE1,

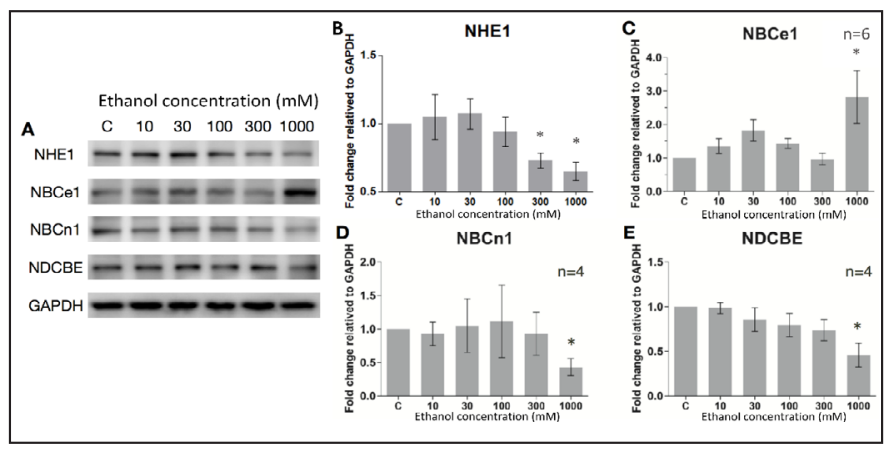
NBCe1, NBCn1 and NDCBE to GAPDH

that were averaged for 4 to 6 experiments similar to those shown in A, respectively. ${ }^{*} \mathrm{p}<0.05$ or ${ }^{* *} \mathrm{p}<0.01$ verse to control.

progression by promoting proliferation, the evasion of apoptosis, metabolic adaptation, migration and invasion [46]. Indeed, as expectation, we have found that the value of original resting $\mathrm{pH}_{\mathrm{i}}$ of OEC-M1 is quite alkaline (7.49 and 7.35) under HEPES-buffered Tyrode and $\mathrm{HCO}_{3}{ }^{-}$-buffered Tyrode solution, respectively (Fig. 2). Such alkaline $\mathrm{pH}_{\mathrm{i}}$ value was shifted to a new, steady-state but acidic $\mathrm{pH}_{\mathrm{i}}$ value (7.0 and 7.03) after a few intracellular acid/base impacts of $\mathrm{NH}_{4} \mathrm{Cl}$ pre-pulse, under HEPES-buffered Tyrode and $\mathrm{HCO}_{3}^{-}$-buffered Tyrode solution, respectively (Fig. 2). Such acidic steady-state $\mathrm{pH}_{i}$ value is not only significantly lower than that of highly proliferated cells, i.e. embryonic stem cells and cancer cells $(\sim 7.4)$ $[43,46,47]$, but also lower than that of normal animal and human mature cells $(\sim 7.2)[23-$ $25,28,48]$. As steady-state $\mathrm{pH}_{\mathrm{i}}$ is a balance through the combined operation of passive intracellular buffering power and active transmembrane $\mathrm{pH}_{\mathrm{i}}$ transporters [24-26], therefore, the shift of $\sim 0.4 \mathrm{pH}_{\mathrm{i}}$ units from alkaline to acidic means a dramatic kinetic change in the $\mathrm{pH}_{\mathrm{i}}$ regulating mechanism. Whether such shift from alkaline to acidic after the intracellular acid/base impacts implies the typical and flexible character of $\mathrm{pH}_{\mathrm{i}}$ regulating mechanism of OEC-M1 cells awaits further study. For example, the acidification after acid/base impact(s) in OECM1 is probably due to the limitation of cytosolic buffering capacity, and easily be saturated. Alternatively, the activity of the acid loaders, such as AE and CHE, is another factor to decide the steady-state $\mathrm{pH}_{\mathrm{i}}$. Therefore, the characterization of active acid loaders 
and passive cytosolic buffering capacity under different pathophysiological conditions wait to be examined in OEC-M1 cells. Indeed, oral cavity is subject to be exposed to various $\mathrm{pH}$ conditions. For example, in the inflammatory tissue, a lower value of $\mathrm{pH}_{\mathrm{e}}$ (i.e. tissue acidosis) is frequently observed [49]. Also, during the process of abscess development, the oral cavity is exposed to lactic acid, the predominant by-product of caries-associated bacteria, and exhibits a low level of $\mathrm{pH}(\sim 4.9)$ [50]. On the other hand, mineral trioxide aggregate (MTA), a potential root-end filling material, produces an initial $\mathrm{pH}_{\mathrm{e}}$ of 10.2 , which rises to 12.5 at 3 hours after mixing [51]. Therefore, the special character of shifting $\mathrm{pH}_{\mathrm{i}}$ from alkaline to acidic after intracellular acid/base impacts might provide another new maneuver on developing related medicines to cure OEC-M1 cells.

\section{Potential role of inhibitors/activators of isoforms of NHE and NBC in clinical setting}

In mammalian cells, in addition to the ubiquitous two acid extruders, i.e. NHE and NBC, the vacuolar- $\mathrm{H}^{+}$-ATPase (V-ATPase) utilizes ATP to pump protons to extracellular environment. V-ATPase has been reported as an important $\mathrm{pH}_{\mathrm{i}}$ regulator in many different types of cancers and positively correlated to cancer invasion and metastasis [52, 53]. In our present study, we provide straightforward and convincing functional evidence that NHE and NBC are functionally responsible for acid extrusion, following induced acidosis in OEC-M1 cells, as shown in Figs. 2-3. In other words, surprisingly, the V-ATPase has not been found to play a role in the functional $\mathrm{pH}_{\mathrm{i}}$ recovery following induced intracellular acidification in OEC-M1 cells. This is a very unique character of OEC-M1 cells, and can provide a new strategy while apply possible treatment on oral cancer in clinic.

Furthermore, by using Western blot technique, apart from the housekeeping NHE1, we have provided the directly molecular evidence of existence of $3 \mathrm{NBC}$ isoforms, i.e. NBCn1, NBCe1 and NDCBE, in the OEC-M1 cells (Fig. 7A). The result of 3 isoforms of NBC in OEC-M1 is different to that found in vascular cells of mouse, rat and human models. The difference is probably due to differences in species/organs. Moreover, some isoforms of NBC might play a vital role on the development of oral carcinogenesis. Indeed, it has been found that the enhancement of NBC activity is the main reason for an alkaline shift ( $\sim 0.3$ units of magnitude) in steady-state intracellular $\mathrm{pH}$ of human primary breast carcinomas compared to normal breast tissue [54]. Furthermore, upregulated NBCn1 during human breast carcinogenesis contributes to the characteristic acid distribution within human breast carcinomas [54]. Therefore, our present study has provided a new strategy of potential role of inhibitors/ activators of isoforms of NHE and NBC in clinical setting. Moreover, further study on pinpointing the specific isoform(s) expression for OEC-M1/oral cancer tissues development and progression waits to be examined. For example, in the future, normal and cancer tissues from clinical patients can be collected to further identify the expression of isoforms of NHE and NBC by IHC. Moreover, the effects of knock down or overexpression of specific isoform will be checked to observe its effects on cellular growth, apoptosis, migration, invasion and metabolism of cancer cells.

\section{The acute and chronic effect of ethanol on intracellular $p H$ regulating mechanism}

Our present study has, for the first time, provided straightforward evidence about acute (Fig. 3, 4 and 6) and chronic (i.e. 24 hr; Figs. 4 and 7) effects of various concentrations (i.e. 10$1000 \mathrm{mM}$ ) of ethanol on $\mathrm{pH}_{\mathrm{i}}$ regulating mechanism. Note that the changes in $\mathrm{pH}_{\mathrm{i}}$ upon a $24 \mathrm{~h}$ ethanol treatment are about up to five or even six times higher (Fig. 4F) than those observed immediately after alcohol exposure (Fig. 4E). The ethanol-induced changes on expression of acid loaders, i.e. NHE and NBC isoforms (Fig. 7), might be the reason to account for the higher extend on $\mathrm{pH}_{\mathrm{i}}$ changes upon $24 \mathrm{~h}$ ethanol treatment. Our present study shows that ethanol concentration-dependently decreased NHE1 activity, while showed a concentrationdependent but biphasic effect, on NBCs activity, increase following decrease (Fig. 6). As NHE and $\mathrm{NBC}$ contributed together for acid extruding in $\mathrm{CO}_{2} / \mathrm{HCO}_{3}^{-}$-buffered solution (see Fig. 3), therefore, considering the ethanol induced inhibition on NHE activity, the slightly ethanol induced increases on $\mathrm{pH}_{\mathrm{i}}$ recovery shown in Fig. 6 represent a larger scale of ethanol-induced 
changes of NBC activity. For example, $1000 \mathrm{mM}$ ethanol induced changes is smaller $(\sim 50 \%)$ under $\mathrm{CO}_{2} / \mathrm{HCO}_{3}$--buffered condition than that in HEPES ( - -86\%) (Fig. 6D).

Moreover, chronic exposure to higher concentrations of ethanol significantly inhibited the expression of NHE1, NBCn1 and NDCBE, while up-regulated NBCe1 (Fig. 7). Because an acidic $\mathrm{pH}$ condition induce growth arrest or cell death [55], thus change of any one of these $\mathrm{H}^{+}$-equivalent transporters may play a significant role in the progression of carcinogenesis of oral cancer. Recently, Kim et al. have reported that ethanol $(10 \sim 30 \mathrm{mM})$ induces cell proliferation of HepG2 cells, activates NHE1 and anti-apopotitc Bcl-2 through enhancing the activities of ERK1 and p90rsk, and the maximum effects are shown at the concentration of $20 \mathrm{mM}$ both [22]. Also, in our present study, the similar trend of ethanol (10 30 mM) on NHE1 expression has been found (Fig. 7). Indeed, p90rsk, hyperactive NHE1 even at the resting $\mathrm{pH}$ and the resulting cellular alkalinization have been reported to be directly related to uncontrolled proliferation in malignancy cells [22]. Thus, p90rsk that regulates cellular proliferation, as well as NHE1, may be an important molecule for therapeutic targeting in ethanol-induced carcinoma progression. Hence, our present study has provided a promising target for new treatment strategies to prevent or cure alcohol consumption-associated oral diseases and cancers.

\section{Conclusion}

In the present study, we have, for the first time, provided straightforward, functional and molecular evidence of coexistence of NHE1, NBCn1, NDCBE and NBCe1 for acid extruding mechanism in the OEC-M1 cells. Moreover, we have found that ethanol affects $\mathrm{pH}_{\mathrm{i}}$ value by changing function and expression of NHE1 and NBC isoforms.

\section{Acknowledgments}

This work was supported in part by Ministry of Science and Technology Grants (Grant No.: MOST 105-2320-B-016-011, MOST 106-2320-B-016-003-MY2), National Defense Medical Center (Grant No: MAB-104-M079; MAB-105-10; MAB-106-033), Teh-Tzer Study Group for Human Medical Research Foundation (Grant No: A1061037; A1061054), and Tri-Service General Hospital Grants (Grant No: TSGH-C106-022; TSHG-C106-013), Taipei, Taiwan, R.O.C.

\section{Disclosure Statement}

The authors declare that there is no Disclosure Statement regarding the publication of this paper.

\section{References}

1 Ghantous Y, Abu Elnaaj I: [GLOBAL INCIDENCE AND RISK FACTORS OF ORAL CANCER]. Harefuah 2017;156:645-649.

-2 Ghantous Y, Yaffi V, Abu-Elnaaj I: [Oral cavity cancer: epidemiology and early diagnosis]. Refuat Hapeh Vehashinayim (1993) 2015;32:55-63, 71.

-3 Hanahan D, Weinberg RA: Hallmarks of cancer: the next generation. Cell 2011;144:646-674.

4 Gallagher FA, Kettunen MI, Day SE, Hu DE, Ardenkjaer-Larsen JH, Zandt R, Jensen PR, Karlsson M, Golman $\mathrm{K}$, Lerche MH, Brindle KM: Magnetic resonance imaging of $\mathrm{pH}$ in vivo using hyperpolarized 13C-labelled bicarbonate. Nature 2008;453:940-943. 


\section{Cellular Physiology Cell Physiol Biochem 2018;47:2056-2068

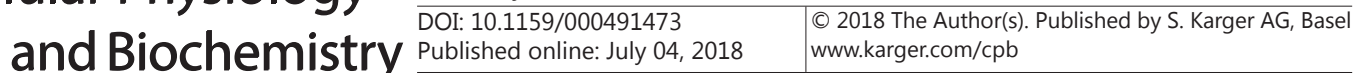

5 Gillies RJ, Raghunand N, Karczmar GS, Bhujwalla ZM: MRI of the tumor microenvironment. J Magn Reson Imaging 2002;16:430-450.

6 Helmlinger G, Sckell A, Dellian M, Forbes NS, Jain RK: Acid production in glycolysis-impaired tumors provides new insights into tumor metabolism. Clin Cancer Res 2002;8:1284-1291.

-7 Tannock IF, Rotin D: Acid pH in tumors and its potential for therapeutic exploitation. Cancer Res 1989;49:4373-4384.

-8 Stock C, Gassner B, Hauck CR, Arnold H, Mally S, Eble JA, Dieterich P, Schwab A: Migration of human melanoma cells depends on extracellular pH and Na+/H+ exchange. J Physiol 2005;567:225-238.

-9 Reshkin SJ, Bellizzi A, Albarani V, Guerra L, Tommasino M, Paradiso A, Casavola V: Phosphoinositide 3-kinase is involved in the tumor-specific activation of human breast cancer cell $\mathrm{Na}(+) / \mathrm{H}(+)$ exchange, motility, and invasion induced by serum deprivation. J Biol Chem 2000;275:5361-5369.

10 Stuwe L, Muller M, Fabian A, Waning J, Mally S, Noel J, Schwab A, Stock C: pH dependence of melanoma cell migration: protons extruded by NHE1 dominate protons of the bulk solution. J Physiol 2007;585:351-360.

11 Busco G, Cardone RA, Greco MR, Bellizzi A, Colella M, Antelmi E, Mancini MT, Dell'Aquila ME, Casavola V, Paradiso A, Reshkin SJ: NHE1 promotes invadopodial ECM proteolysis through acidification of the periinvadopodial space. Faseb j 2010;24:3903-3915.

12 Abdelazeem KNM, Singh Y, Lang F, Salker MS: Negative Effect of Ellagic Acid on Cytosolic pH Regulation and Glycolytic Flux in Human Endometrial Cancer Cells. Cell Physiol Biochem 2017;41:2374-2382.

13 Kiss L, Korn SJ: Modulation of N-type Ca2+ channels by intracellular pH in chick sensory neurons. J Neurophysiol 1999;81:1839-1847.

14 Grinstein S, Woodside M, Sardet C, Pouyssegur J, Rotin D: Activation of the $\mathrm{Na}+\mathrm{H}+$ antiporter during cell volume regulation. Evidence for a phosphorylation-independent mechanism. J Biol Chem 1992;267:2382323828.

15 Boedtkjer E, Aalkjaer C: Acid-base transporters modulate cell migration, growth and proliferation: Implications for structure development and remodeling of resistance arteries? Trends Cardiovasc Med 2013;23:59-65.

16 Teshima Y, Akao M, Jones SP, Marban E: Cariporide (HOE642), a selective Na+-H+ exchange inhibitor, inhibits the mitochondrial death pathway. Circulation 2003;108:2275-2281.

17 Moolenaar WH: Effects of growth factors on intracellular pH regulation. Annu Rev Physiol 1986;48:363376.

18 Pouyssegur J, Franchi A, L’Allemain G, Paris S: Cytoplasmic pH, a key determinant of growth factor-induced DNA synthesis in quiescent fibroblasts. FEBS Lett 1985;190:115-119.

19 Belaud-Rotureau MA, Leducq N, Macouillard Poulletier de Gannes F, Diolez P, Lacoste L, Lacombe F, Bernard P, Belloc F: Early transitory rise in intracellular pH leads to Bax conformation change during ceramide-induced apoptosis. Apoptosis 2000;5:551-560.

20 Matsubara K, Kubota M, Adachi S, Kuwakado K, Hirota H, Wakazono Y, Akiyama Y, Mikawa H: Different mode of cell death induced by calcium ionophore in human leukemia cell lines: possible role of constitutive endonuclease. Exp Cell Res 1994;210:19-25.

-21 Lagadic-Gossmann D, Huc L, Lecureur V: Alterations of intracellular pH homeostasis in apoptosis: origins and roles. Cell Death Differ 2004;11:953-961.

-22 Kim HS, Kim SJ, Bae J, Wang Y, Park SY, Min YS, Je HD, Sohn UD: The p90rsk-mediated signaling of ethanolinduced cell proliferation in HepG2 cell line. Korean J Physiol Pharmacol 2016;20:595-603.

-23 Tsai YT, Liu JY, Lee CY, Tsai CS, Chen MH, Ou CC, Chen WH, Loh SH: Functional characterization of transmembrane intracellular $\mathrm{pH}$ regulators and mechanism of alcohol-induced intracellular acidosis in human umbilical cord blood stem cell-like cells. J Cardiovasc Pharmacol 2011;58:589-601.

24 Tsai YT, Lee CY, Hsu CC, Chang CY, Hsueh MK, Huang EY, Tsai CS, Loh SH: Effects of urotensin II on intracellular pH regulation in cultured human internal mammary artery smooth muscle cells. Peptides 2014;56:173-182.

25 Loh S-H, Lee C-Y, Tsai Y-T, Shih S-J, Chen L-W, Cheng T-H, Chang C-Y, Tsai C-S: Intracellular Acid-Extruding Regulators and the Effect of Lipopolysaccharide in Cultured Human Renal Artery Smooth Muscle Cells. PLoS ONE 2014;9:e90273.

-26 Loh SH, Sun B, Vaughan-Jones RD: Effect of Hoe 694, a novel Na(+)-H+ exchange inhibitor, on intracellular pH regulation in the guinea-pig ventricular myocyte. British Journal of Pharmacology 1996;118:19051912. 


\section{Cellular Physiology Cell Physiol Biochem 2018;47:2056-2068 \begin{tabular}{ll|l} 
and Biochemistry Published onlIne: July 04, 2018 & $\begin{array}{l}\text { C } 2018 \text { The Author(s). Published by S. Karger AG, Basel } \\
\text { www.karger.com/cpb }\end{array}$ \\
\hline
\end{tabular}}

27 Loh SH, Jin JS, Tsai CS, Chao CM, Chiung CS, Chen WH, Lin CI, Chuang CC, Wei J: Functional evidence for intracellular acid extruders in human ventricular myocardium. Jpn J Physiol 2002;52:277-284.

-28 Loh SH, Chen WH, Chiang CH, Tsai CS, Lee GC, Jin JS, Cheng TH, Chen JJ: Intracellular pH regulatory mechanism in human atrial myocardium: functional evidence for $\mathrm{Na}(+) / \mathrm{H}(+)$ exchanger and $\mathrm{Na}(+) / \mathrm{HCO}(3)$ (-) symporter. J Biomed Sci 2002;9:198-205.

-29 Yamamoto T, Swietach P, Rossini A, Loh SH, Vaughan-Jones RD, Spitzer KW: Functional diversity of electrogenic $\mathrm{Na}+\mathrm{HCO} 3$ - cotransport in ventricular myocytes from rat, rabbit and guinea pig. J Physiol 2005;562:455-475.

-30 Lagadic-Gossmann D, Buckler KJ, Vaughan-Jones RD: Role of bicarbonate in pH recovery from intracellular acidosis in the guinea-pig ventricular myocyte. J Physiol 1992;458:361-384.

-31 Romero MF, Fulton CM, Boron WF: The SLC4 family of HCO 3 - transporters. Pflugers Arch 2004;447:495509.

-32 Chiva-Blanch G, Arranz S, Lamuela-Raventos RM, Estruch R: Effects of wine, alcohol and polyphenols on cardiovascular disease risk factors: evidences from human studies. Alcohol Alcohol 2013;48:270-277.

33 Rantakomi SH, Laukkanen JA, Kurl S, Kauhanen J: Binge drinking and the progression of atherosclerosis in middle-aged men: an 11-year follow-up. Atherosclerosis 2009;205:266-271.

-34 Dylawerska A, Barczak W, Wegner A, Golusinski W, Suchorska WM: Association of DNA repair genes polymorphisms and mutations with increased risk of head and neck cancer: a review. Med Oncol 2017;34:197.

-35 Chen KM, Schell TD, Richie JP, Jr., Sun YW, Zhang SM, Calcagnotto A, Aliga C, Gowda K, Amin S, El-Bayoumy $\mathrm{K}$ : Effects of chronic alcohol consumption on DNA damage and immune regulation induced by the environmental pollutant dibenzo [a,l]pyrene in oral tissues of mice. J Environ Sci Health C Environ Carcinog Ecotoxicol Rev 2017;10.1080/10590501.2017.13915140.

-36 Shirpoor A, Gharalari FH, Rasmi Y, Heshmati E: Ginger extract attenuates ethanol-induced pulmonary histological changes and oxidative stress in rats. J Biomed Res 2017;10.7555/jbr.31.20160151

37 Goldstein BY, Chang SC, Hashibe M, La Vecchia C, Zhang ZF: Alcohol consumption and cancers of the oral cavity and pharynx from 1988 to 2009: an update. Eur J Cancer Prev 2010;19:431-465.

-38 Varoni EM, Lodi G, Iriti M: Ethanol versus Phytochemicals in Wine: Oral Cancer Risk in a Light Drinking Perspective. Int J Mol Sci 2015;16:17029-17047.

-39 Giacosa A, Adam-Blondon AF, Baer-Sinnott S, Barale R, Bavaresco L, Di Gaspero G, Dugo L, Ellison RC, Gerbi V, Gifford D, Janssens J, La Vecchia C, Negri E, Pezzotti M, Santi L, Santi L, Rondanelli M: Alcohol and wine in relation to cancer and other diseases. Eur J Cancer Prev 2012;21:103-108.

40 Anantharaman D, Marron M, Lagiou P, Samoli E, Ahrens W, Pohlabeln H, Slamova A, Schejbalova M, Merletti F, Richiardi L, Kjaerheim K, Castellsague X, Agudo A, Talamini R, Barzan L, Macfarlane TV, Tickle M, Simonato L, Canova C, Conway DI, McKinney PA, Thomson P, Znaor A, Healy CM, McCartan BE, Hashibe M, Brennan P, Macfarlane GJ: Population attributable risk of tobacco and alcohol for upper aerodigestive tract cancer. Oral Oncol 2011;47:725-731.

41 Tsai CS, Loh SH, Jin JS, Hong GJ, Lin HT, Chiung CS, Chang CY: Effects of alcohol on intracellular pH regulators and electromechanical parameters in human myocardium. Alcohol Clin Exp Res 2005;29:17871795.

-42 Roos A, Boron WF: Intracellular pH. Physiol Rev 1981;61:296-434.

-43 Ulmschneider B, Grillo-Hill BK, Benitez M, Azimova DR, Barber DL, Nystul TG: Increased intracellular pH is necessary for adult epithelial and embryonic stem cell differentiation. J Cell Biol 2016;215:345-355.

44 Meima ME, Webb BA, Witkowska HE, Barber DL: The sodium-hydrogen exchanger NHE1 is an Akt substrate necessary for actin filament reorganization by growth factors. J Biol Chem 2009;284:2666626675.

45 Buckler KJ, Vaughan-Jones RD, Peers C, Lagadic-Gossmann D, Nye PC: Effects of extracellular pH, PCO2 and HCO3- on intracellular pH in isolated type-I cells of the neonatal rat carotid body. J Physiol 1991;444:703721.

46 Webb BA, Chimenti M, Jacobson MP, Barber DL: Dysregulated pH: a perfect storm for cancer progression. Nat Rev Cancer 2011;11:671-677.

47 Asgharzadeh MR, Barar J, Pourseif MM, Eskandani M, Jafari Niya M, Mashayekhi MR, Omidi Y: Molecular machineries of $\mathrm{pH}$ dysregulation in tumor microenvironment: potential targets for cancer therapy. Bioimpacts 2017;7:115-133. 
-48 Leem CH, Lagadic-Gossmann D, Vaughan-Jones RD: Characterization of intracellular pH regulation in the guinea-pig ventricular myocyte. J Physiol 1999;517:159-180.

49 Steen KH, Steen AE, Reeh PW: A dominant role of acid pH in inflammatory excitation and sensitization of nociceptors in rat skin, in vitro. J Neurosci 1995;15:3982-3989.

50 Hojo S, Komatsu M, Okuda R, Takahashi N, Yamada T: Acid profiles and pH of carious dentin in active and arrested lesions. J Dent Res 1994;73:1853-1857.

-51 Torabinejad M, Hong CU, McDonald F, Pitt Ford TR: Physical and chemical properties of a new root-end filling material. J Endod 1995;21:349-353.

-52 Rojas JD, Sennoune SR, Maiti D, Bakunts K, Reuveni M, Sanka SC, Martinez GM, Seftor EA, Meininger CJ, Wu G, Wesson DE, Hendrix MJ, Martinez-Zaguilan R: Vacuolar-type H+-ATPases at the plasma membrane regulate $\mathrm{pH}$ and cell migration in microvascular endothelial cells. Am J Physiol Heart Circ Physiol 2006;291:H1147-1157.

53 Fais S, De Milito A, You H, Qin W: Targeting vacuolar H+-ATPases as a new strategy against cancer. Cancer Res 2007;67:10627-10630.

54 Lee S, Mele M, Vahl P, Christiansen PM, Jensen VE, Boedtkjer E: Na+,HCO3- -cotransport is functionally upregulated during human breast carcinogenesis and required for the inverted $\mathrm{pH}$ gradient across the plasma membrane. Pflugers Arch 2015;467:367-377.

55 Hirose Y, Yamaguchi M, Kawabata S, Murakami M, Nakashima M, Gotoh M, Yamamoto T: Effects of Extracellular pH on Dental Pulp Cells In vitro. J Endod 2016;42:735-741. 